\title{
A Qualitative Study of Internal Wave Ship Wakes: Dependence on Environmental Conditions and Experimental Parameters
}

C.J. Mullenhoff and J.M. Brase

April 24, 1995

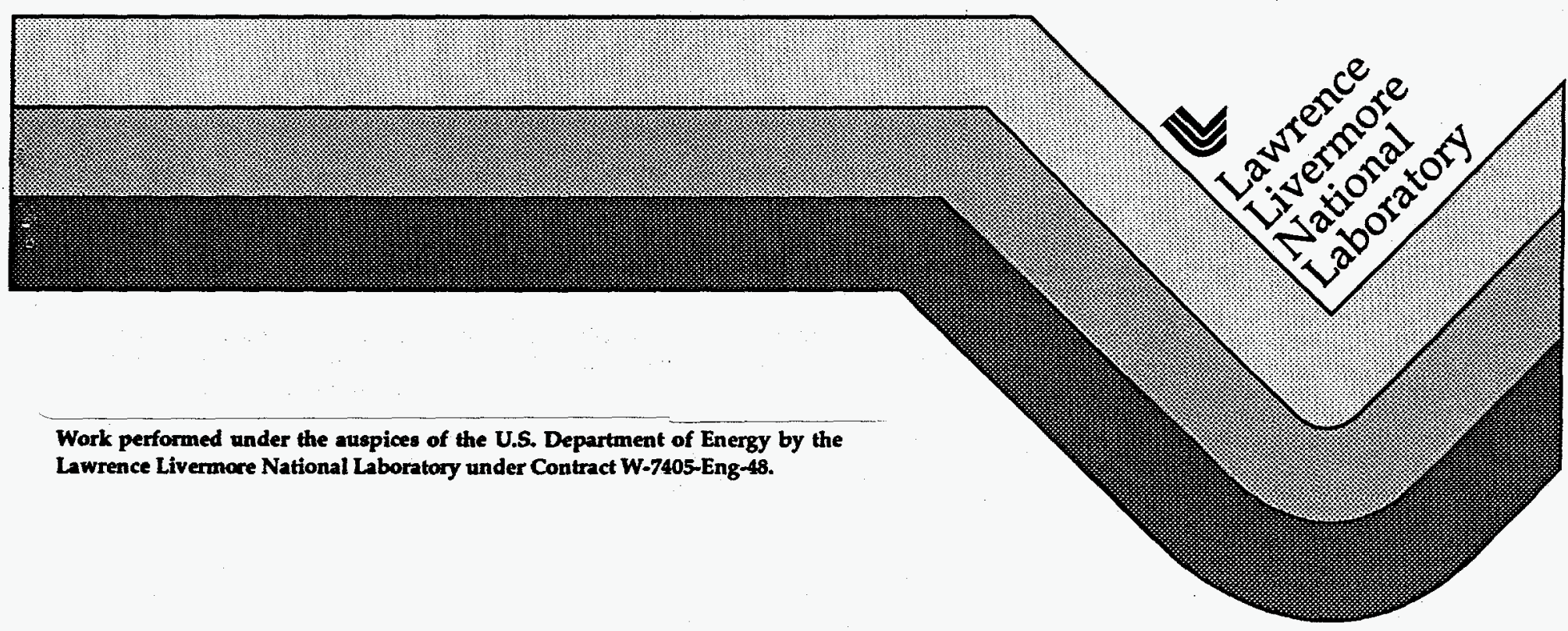




\section{DISCLAIMER}

This document was prepared as an account of work sponsored by an agency of the United States Government. Neither the United States Government nor the University of California nor any of their employees, makes any warranty, express or implied, or assumes any legal liability or responsibility for the accuracy, completeness, or usefulness of any information, apparatus, product, or process disclosed, or represents that its use would not infringe privately owned rights. Reference herein to any specific commercial products, process, or service by trade name, trademark, manufacturer, or otherwise, does not necessarily constitute or imply its endorsement, recommendation, or favoring by the United States Government or the University of California. The views and opinions of authors expressed herein do not necessarily state or reflect those of the United States Government or the University of California, and stiall not be used for advertising or product endorsement purposes.

This report has been reproduced directly from the best available copy.

Available to DOE and DOE contractors from the Office of Scientific and Technical Information

P.O. Box 62, Oak Ridge, TN 37831

Prices available from (615) 576-8401, FTS 626.8401

Available to the public from the

National Technical Information Service

US. Department of Commerce

5285 Port Royal Rd.,

Springfield, VA 22161 


\section{DISCLAIMER}

Portions of this document may be illegible in electronic image products. Images are produced from the best available original document. 


\title{
A Qualitative Study of Internal Wave Ship Wakes: Dependence on Environmental Conditions and Experimental Parameters
}

\author{
C.J. Mullenhoff, J.M. Brase
}

\section{Introduction}

For the past several years the UK-US Radar Ocean Imaging Program has conducted a series of field experiments with the primary purpose of gathering real aperture radar (RAR) imagery at low grazing angle of ship-generated internal wave (IW) wakes. The first observations with RAR's were made in the 1989 Loch Linnhe experiment where it was observed that radar images at low grazing angles (LGA) of approximately six degrees had significantly higher modulation levels than SAR images made at higher grazing angles of 35 - 65 degrees [1]. These initial observations have led to several more experiments designed to verify the phenomenon and to test its dependence on experimental and environmental conditions. A parallel effort began to develop theoretical models of the LGA imaging process.

Through this series of experiments we have developed an extensive database of radar imagery and supporting environmental data. The objective of this report is twofold:

1. To describe the database and the associated space of parameters. We will look at the coverage of the parameter space within the database and at areas which should be covered.

2. To take an initial look at the dependence of qualitative modulation strength on the experimental and environmental parameters. This first look will indicate the strongest dependencies which can then be studied in more detail.

Section 2 describes the experimental database and Section 3 discusses the parameter space, image quality, and their relationships based on the images in the database. In Section 4 we summarize our conclusions and make recommendations for both future analyses and experiments.

\section{The ROI database}

The database used in this report includes images from three experiments conducted from 1991 - 1994 as part of the UK-US Radar Ocean Imaging Program. For the 1989 and 1990 Loch Linnhe experiments where LGA imaging was first demonstrated we have only short image segments and have not included them in this analysis. Loch Linnhe 1991 and Sound of Sleat 1991 were segments of one experiment, West Coast Scotland Experiment 1991. In this section we will give a brief description of each experiment. The complete image database is summarized in Table 1.

The total ship runs column contains the number of times the wake-generating ship passed through the experiment site during the experiment. The acquired images column contains the number of times that the radar system acquired data while the usable images column contains the number of those that images which are of adequate quality to use (i.e. no radar problems or strong scatterers such as birds or seals). The strong and weak IW images are those which contain visible IW wakes. The classification into strong and weak categories is discussed (with examples) in Section 3. 


\begin{tabular}{|l||llllll|}
\hline Experiment & $\begin{array}{l}\text { Total ship } \\
\text { runs }\end{array}$ & $\begin{array}{l}\text { Acquired } \\
\text { images }\end{array}$ & $\begin{array}{l}\text { Usable } \\
\text { images }\end{array}$ & $\begin{array}{l}\text { Strong IW } \\
\text { wakes }\end{array}$ & $\begin{array}{l}\text { Weak IW } \\
\text { wakes }\end{array}$ & $\begin{array}{l}\text { No IW } \\
\text { wakes }\end{array}$ \\
\hline \hline $\begin{array}{l}\text { Loch } \\
\text { Linnhe } 91\end{array}$ & 28 & 13 & 13 & 2 & 8 & 3 \\
$\begin{array}{l}\text { Sound of } \\
\text { Sleat 91 }\end{array}$ & 16 & 11 & 11 & 7 & 3 & 1 \\
$\begin{array}{l}\text { Sound of } \\
\text { Sleat 92 } \\
\begin{array}{l}\text { Loch } \\
\text { Linnhe 94 }\end{array}\end{array}$ & 24 & 10 & 10 & 3 & 4 & 3 \\
\hline
\end{tabular}

Table 1. Summary of radar imagery acquired and number of wakes detected in 1991 - 1994 Radar Ocean Imaging experiments

\subsection{Loch Linnhe 1991}

The 1991 Loch Linnhe experiment was the first phase of the 1991 West Coast Scotland experiment; the Loch Linnhe part was held in the upper Loch from July 6 to July 12. Figure 1 shows the geographical location of the experiment sites. The experiment consisted of both airborne intermediate incidence angle SAR's and hillside low grazing angle RAR's imaging ship-generated IW wakes. In this report we will consider only the RAR imagery. The stratification was generally weaker than expected with peak BV frequencies ranging from 0.06 to $0.13 \mathrm{rad} / \mathrm{sec}$. The wind was generally in the cross-look direction.

The wake-generating ships were the Roysterer and the Blue Rover. The characteristics of the target ships are given in Table 2. Two LGA radars were deployed: the Thorn-EMI MCR radar used in the 1989 and 1990 experiments [1] and a $10 \mathrm{GHz}$ step-frequency radar fielded by Hughes and LLNL. Both were operated at 5-6 degrees grazing. In this report we will use imagery supplied by the Hughes radar. The images acquired were generally consistent with those of the Thorn-EMI radar. The Hughes radar was fully polarimetric and had a range resolution of 1.0 meters and a temporal sample period of $6.4 \mathrm{~ms}$ [2]. Table 3 briefly describes the various radars.

There were 28 ship runs in Upper Loch Linnhe. Of these runs 13 produced usable RAR imagery and 10 contained identifiable IW wakes (Table 1). The 1991 experiment is described in detail in [3].

\begin{tabular}{|l||lllll|}
\hline Ship name & $\begin{array}{l}\text { R.V. Colonel } \\
\text { Templer }\end{array}$ & RMAS Collie & $\begin{array}{l}\text { RMAS } \\
\text { Roysterer }\end{array}$ & Arakan & Blue Rover \\
\hline \hline Experiment & LL94 & LL94 & LL/SOS 91- & LL91 & SOS91 \\
& & & 92 & & \\
Length (m) & 56.6 & 29 & 51 & 72 & 141 \\
Beam (m) & 11 & 8 & 12 & 15 & 19 \\
Draft (m) & 5.6 & 4 & 5.5 & 2 & 7 \\
$\begin{array}{l}\text { Displacement } \\
\text { (tons) }\end{array}$ & 1300 & 152 & 1036 & 1050 & 11522 \\
\hline
\end{tabular}

Table 2. Wake-generation ships used as targets in the 1991 - 1994 IW wake imaging experiments. 


\begin{tabular}{|l||lllll|}
\hline Radar & $\begin{array}{l}\text { Frequency } \\
\text { Band(s) }\end{array}$ & $\begin{array}{l}\text { Range } \\
\text { Resolution } \\
(\mathrm{m})\end{array}$ & $\begin{array}{l}\text { Time } \\
\text { Resolution } \\
(\mathrm{msec})\end{array}$ & $\begin{array}{l}\text { No. of } \\
\text { Range cells }\end{array}$ & $\begin{array}{l}\text { Grazing } \\
\text { Angles }^{\circ}\end{array}$ \\
\hline \hline Thorn-EMI 91 & $\mathrm{X}, \mathrm{Ku}$ & 1.5 & 4.0 & 256 & 6.0 \\
Hughes 91 & $\mathrm{X}$ & 1.0 & 6.4 & 256 & 4.5 \\
Hughes 92 & $\mathrm{X}$ & 2.0 & 3.0 & 320 & 5.0 \\
Thorn-EMI 94 & $\mathrm{X}, \mathrm{S}$ & 1.5 & 2.0 or 4.0 & 1024 & 6.0 \\
\hline
\end{tabular}

Table 3. Description of the hillside radars used in the 1991 - 1994 IW wake imaging experiments.

\subsection{Sound of Sleat 1991}

The second phase of the 1991 experiment was held in the Sound of Sleat, a more open ocean like and more weakly stratified site than Loch Linnhe. The peak BV frequencies ranged from 0.03 to $0.06 \mathrm{rad} / \mathrm{sec}$ while the wind direction varied from cross-look to directly into the radar. The experiment was the same as the Loch Linnhe phase except that the Blue Rover replaced the Arakan to provide a very large wake-generating ship. The radars again operated at 5-6 degrees grazing angle. There were 16 ship runs in Sound of Sleat; of these 11 produced usable images and 10 contained IW wakes.

\subsection{Sound of Sleat 1992}

The 1992 Sound of Sleat experiment focused entirely on LGA radar imaging of shipgenerated IW wakes. It was held from June 6 to June 21, 1992 in the same Sound of Sleat site used in 1991. The environmental conditions were very similar to those in 1991 with weak stratification relative to summer Loch Linnhe conditions. The wind directions varied widely.

The wake-generating ship was the Roysterer. The same two LGA radars deployed in the 1991 test were used with the same 5-6 degree grazing angles. Again we will use only the data from the Hughes radar system. There were 24 ship runs during the experiment. Ten runs provided usable radar imagery and, of these, eight IW wakes were observed.

\subsection{Loch Linnhe 1994}

The 1994 experiment was conducted in Upper Loch Linnhe from Sept. 4 to Sept. 17. Its overall objective was to gather additional LGA imagery in stratification stronger than that of the 1991 and 1992 tests. This objective was achieved: we measured peak BV frequencies up to $0.16 \mathrm{rad} / \mathrm{sec}$ for several runs. Wind speeds ranged from 2 to $14 \mathrm{~m} / \mathrm{sec}$; the dominant wind direction was down the Loch - at right angles to the radar beam.

Two wake-generating ships participated in the experiment: the Colonel Templer and the smaller RMAS Collie. The Colonel Templer, at 1300 tons displacement is very similar to the Roysterer which was used in 1991 and 1992; the Collie was intended to produce IW wakes weaker than those produced by Colonel Templer under the same environmental conditions. The only radar used in the test was the Thorn-EMI MCR radar which was placed at a grazing angle of six degrees. It transmitted at both 10 and $3 \mathrm{GHz}$. IW wakes were observed at both frequencies but only the $10 \mathrm{GHz}$ data is used in this study.

The target ships made 56 runs during the test and 51 of them resulted in usable radar images. There were 23 IW wakes observed. The 1994 test is described in detail in [4]. 


\section{Experimental and environmental parameters}

In this section we define the parameter space over which IW wake imagery may vary and we discuss the extent to which the existing database provides adequate information to characterize it. We discuss each parameter and look at the apparent effect on IW image quality. Where possible we discuss the best available models and whether or not they appear consistent with the data.

\subsection{IW wake imagery parameter space}

Many parameters can influence IW wake image quality. In each experiment extensive data are collected characterizing experimental and environmental conditions. We can divide the parameters into two broad classes: experimental parameters are those under the control of the experimenter, particularly characteristics of the wake-generating ship and of the radar system. Environmental parameters are the air-sea conditions which influence the imaging process. Table 4 summarizes the parameters which have been measured or varied throughout the experiment series. The parameters, their ranges of coverage, and their image quality effects will be described in detail in the following section.

\begin{tabular}{|c|c|c|c|}
\hline \multicolumn{2}{|c|}{ Experimental parameters } & \multicolumn{2}{|c|}{ Environmental parameters } \\
\hline Ship displacement & $\begin{array}{l}100,1000,10000 \\
\text { tons }\end{array}$ & Wind speed & $0-15 \mathrm{~m} / \mathrm{s}$ \\
\hline Ship speed & $1-4 \mathrm{~m} / \mathrm{s}$ & $\begin{array}{l}\text { Wind direction } \\
\text { re: look direction }\end{array}$ & $0- \pm 135$ degrees \\
\hline Track angle & $\begin{array}{l}90 \text { degrees to look } \\
\text { direction }\end{array}$ & Air-sea temperature & $-1.1-5.1^{\circ} \mathrm{C}$ \\
\hline $\begin{array}{l}\text { Radar frequency } \\
\text { Grazing angle }\end{array}$ & $\begin{array}{l}3,10,15 \mathrm{GHz} \\
5-6 \text { degrees }\end{array}$ & $\begin{array}{l}\text { Peak BV frequency } \\
\text { Peak BV depth }\end{array}$ & $\begin{array}{l}0.02-0.18 \mathrm{rad} / \mathrm{sec} \\
1.0-17.0 \mathrm{~m}\end{array}$ \\
\hline
\end{tabular}

Table 4. Experimental and environmental parameter space sampled in the experiment database. The left column gives the parameter, the right gives the range of values covered in the database.

\subsection{Image quality versus single parameters}

In this section we will describe each of the parameters in Table 4, their ranges of values in the database, the effects that they have on IW wake imaging, and identify apparent strong dependencies.

In this study image quality is characterized by the subjective visibility of the wake to an experienced human observer. Each image is classified as belonging to one of three categories: strong wake, weak wake, or no wake. Examples of these three categories are shown in Figures 2, 3, and 4 respectively. We plan to extend this study to more quantitative performance measures but, based on our experience, we believe this coarse-grained quality measure to be reliable.

\subsubsection{Ship displacement}

The first parameter we consider is the ship displacement. Three different displacements have been used in the experiments: approximately 100,1000, and 10000 tons. The displacement directly determines the direct perturbation of the water column and therefore should have a 
strong influence on IW magnitude. This dependence was seen for the two ships used in the 1989 Loch Linnhe experiment [5].

In Figure 5 we show image quality versus ship displacement. We can clearly see that large 10000 ton displacement ship appears more likely to generate strong IW wakes while the small ship is more likely to generate a weak wake or no wake at all. Note that the total number of images in each class is given below the bars. There are few images in either the small or large ship classes so these observations may not be definitive. For the remaining parameter comparisons we will eliminate this apparent strong dependence by using only the 1000 ton class of results which represent the majority of images.

\subsubsection{Ship speed}

The wake generating ships have been run at speeds from 1 to $4 \mathrm{~m} / \mathrm{sec}$. The results are shown in Figure 6. We see a fairly clear trend toward stronger wakes at lower speeds. This is consistent with the hypothesis that the dominant IW generation mechanism is hull displacement, whose strength scales inversely with ship speed.

\subsubsection{Wind speed}

Wind speeds for images in the database range from 0 to $15 \mathrm{~m} / \mathrm{sec}$. The image quality dependence is shown in Figure 7. There does not appear to be a strong relationship between wind speed and the image quality - although at the highest wind speeds $(8-15 \mathrm{~m} / \mathrm{s})$ there were very few strong wakes.

\subsubsection{Wind direction}

The wind direction is measured relative to the radar look direction - a zero wind angle means that the wind is blowing directly towards the radar. Wind angle in the experiments, because of the hillside radar sites have mainly been in the cross-look direction. There are a few images with small wind angles and no images with the wind blowing away from the radar.

Based on previous experience in analyzing LGA imagery, we expect to see a strong dependence of image quality on wind angle. Although there is no existing model which predicts this dependence, nearly all strong IW wake images prior to the 1994 experiment resulted from images with small wind angles. This trend is clearly seen in the data of Figure 8 but not as strongly as we might have thought. This is probably due to the 1994 data where we had a set of good wake images with cross-look winds due to very strong stratification. We will need to look at dependencies of image quality on multiple parameters to separate the effects.

\subsubsection{Air-sea temperature difference}

The air-sea temperature difference is a measure of the stability of the air near the water surface. A negative value (water temperature $>$ air temperature) can indicate turbulent air motion which has been observed in SAR imagery of the ocean [6]. In general, instability has obscured surface features in radar images but here, in Figure 9, we see some evidence of the opposite at LGA. There are fewer cases in the database with this measurement because it was made only in the 1994 Loch Linnhe experiment. The small number of cases $=$ makes it impossible to draw firm conclusions but this parameter is certainly one that should be measured in future experiments. 


\subsubsection{Peak BV frequency}

The peak BV frequency is a measure of the degree of stratification of the water column. It is the peak value of the BV profile. In general we would expect to see stronger IW's for a higher peak BV frequency than for a lower frequency, all else equal. The other important stratification parameter is the depth of the stratification; it is considered in the next subsection.

IW wake image quality is plotted versus peak BV profile in Figure 10. The database has values which range from 0.02 to $0.17 \mathrm{rad} / \mathrm{sec}$. These are fairly strong stratifications; typical open ocean peak BV frequencies are of order $10^{-2}$ to $10^{-3} \mathrm{rad} / \mathrm{sec}$. The data does not show a clear trend in the stratification categories. The dependence is probably hidden in this single parameter study by equally strong dependencies on other parameters.

\subsubsection{Peak BV depth}

In addition to the degree of stratification measured by the peak BV frequency, the other important parameter in determining the quality of the IW image is the depth of the peak BV frequency. Qualitatively, a very deep stratification will not be disturbed by a ship and IW's generated will produce weaker surface currents. The quantitative relationship between the depth of the stratification and the IW current magnitude is complex; it is not clear how strong a relationship we should see.

The image quality versus peak BV depth is plotted in Figure 11. The stratification depths have ranged from less than 1 meter in Loch Linnhe to 17 meters in Sound of Sleat. These are very shallow profiles - more typical open ocean depths would be 30 to $100+$ meters. We do not see a strong dependence on depth at the shallow levels but when the depth exceeds 4 meters we see fewer IW wakes.

\section{Conclusions}

We must make a general note of caution in interpreting the results presented here. We are attempting to analyze a relatively small data set that is dependent on many parameters; the statistical significance of the database is very questionable. The results here should be taken as general indications, not as proven fact. The main remedy for this situation is, of course, to collect more data. Our hope is that by doing these early analyses it may become clearer which parts of the parameter space should get the most attention.

One of the strongest and clearest trends appears to be associated with the wake-generating ships - particularly their displacement but also their speed. We will continue to look closely at the speed since the trend depends mainly on the behavior of the small number (9) of $1 \mathrm{~m} / \mathrm{s}$ runs.

Stratification parameters appear to affect image quality in one of the general ways that we would expect: we see fewer clear IW wakes as the stratification gets deep. The dependence on peak BV frequency is probably hidden by other parameter dependencies. The possibility of a dependence on atmospheric stability in opposite the usual sense is very interesting but we need more data to study the effect.

Dependence on wind seems to follow the preliminary indications: there is only a weak dependence on wind speed except at the extremes while wind direction appears to be quite $=$ important. Looking into the wind with the radar leads to better image quality. We need better wind direction coverage in the database; most of the data has wind from the side. We 
actually have no runs with wind from behind the radar. The need for better wind direction coverage will drive the types of radar platforms we will field at future experiments - away from stationary hillside systems to mobile platforms such as fixed wind aircraft, helicopters, and aerostats which are able to adjust the imaging geometry to the wind direction.

We have no data at LGA with target angles to the radar other than 90 degrees. This is driven by the use of RAR's with long azimuth footprints. We must align the resolution cells along the wake to prevent averaging across them. The apparent solution to this problem is to go to SAR's at LGA which will allow good resolution in both range and azimuth.

Grazing angle is probably an important parameter for IW imaging. We know that we see large improvements as grazing angle decreases from 45 degrees to 5 degrees. But since there are gaps in the database for low/mid grazing angles (10 to 40 degrees) and very low grazing angles ( $<5$ degrees), to fill these gaps should be a high priority for future experiments.

The analysis of the overall ROI database can provide some insight into dependencies of image quality on experimental and environmental parameters. We plan to continue this work and to put it on a more quantitative footing in future reports.

\section{References}

[1] K. Ward, "Low-grazing Angle Radar Measurements of Ship Generated Internal Waves is Scotland 1989-1991", Memorandum No. 4589, DRA Malvern, 1992

[2] S. Lehman, et. al., "Selected Results from LLNL-Hughes RAR for West Coast Scotland Experiment 1991", UCRL-ID-122755, LLNL, January 1993

[3] D. Mantrom, "1991 Joint UK/US West Coast Scotland Experiment Overview Report", CLY-93-067, LLNL, August 1993

[4] D. Mantrom, "Loch Linnhe '94: Test Operations Description and On-Site Analysis, US Activities", UCRL-ID-119197, LLNL, November 1994

[5] G. Watson, R. Chapman, J. Apel "Measurements of the Internal Wave Wake of a Ship in a Highly Stratified Sea Loch", Journal of Geophysical Research, Vol. 97, No. C6, p. 9689-9703, June 1992

[6] F. Monaldo, et. al. "ERS-1 SAR Observations of Internal Waves During the Joint US/Russia Internal Wave Remote Sensing Experiment", IGARSS '94, p. 747-9 


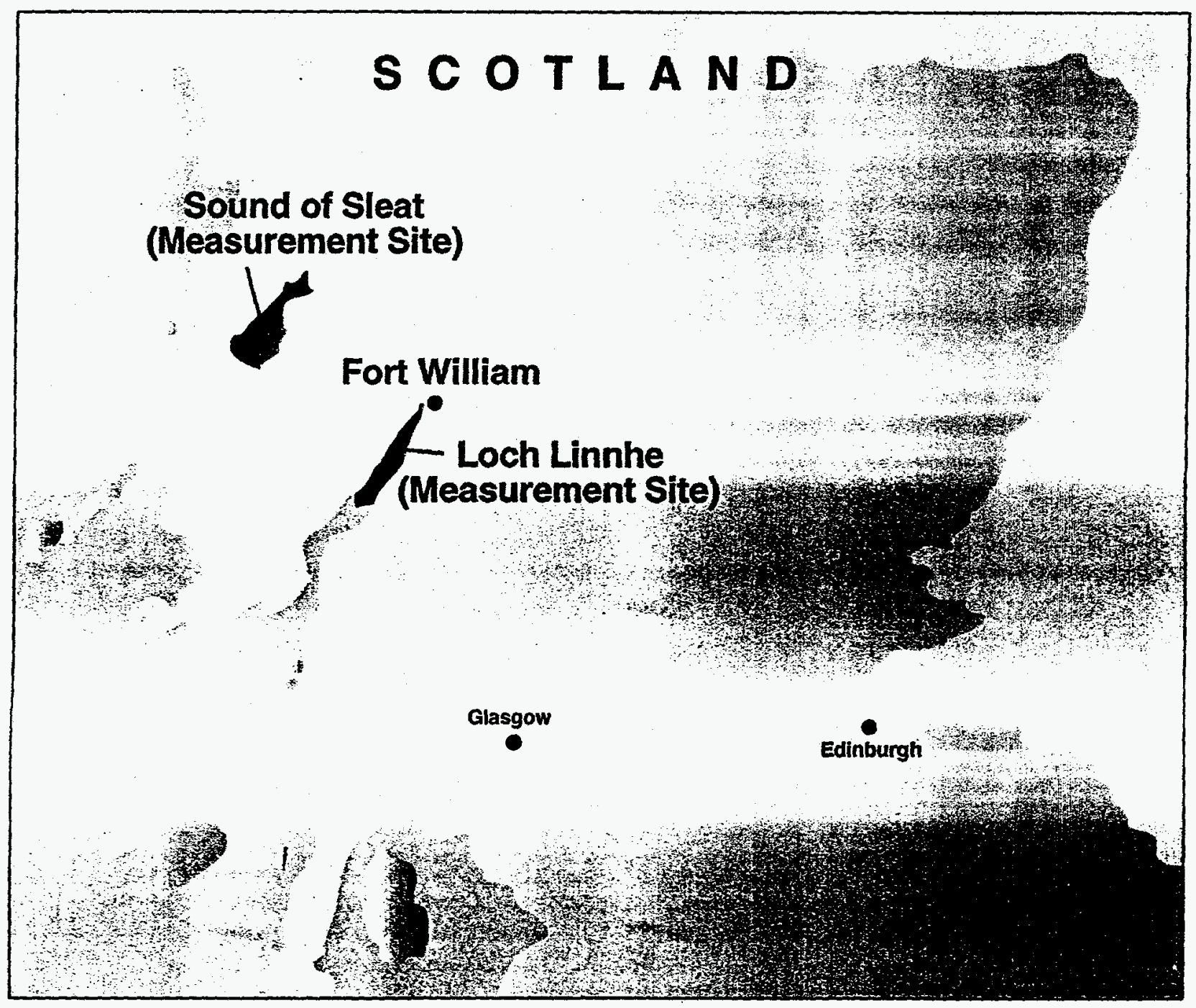

Figure 1. Map of Scotland indicating experiment site locations. 
әуен ou jo әduex :b anbit

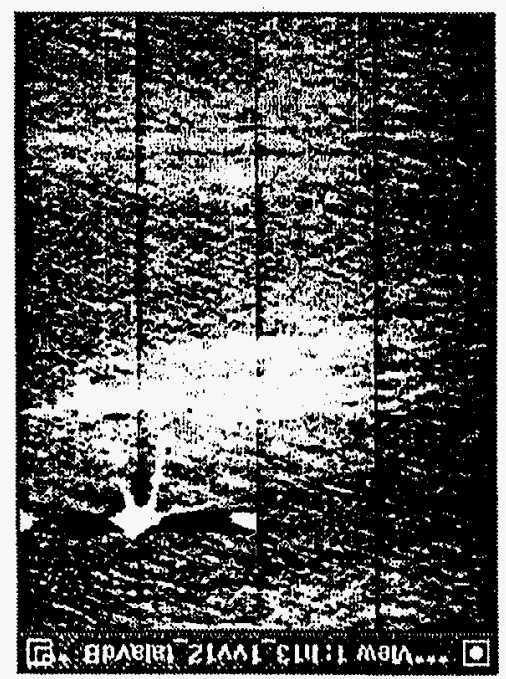

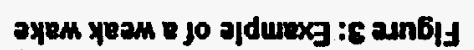

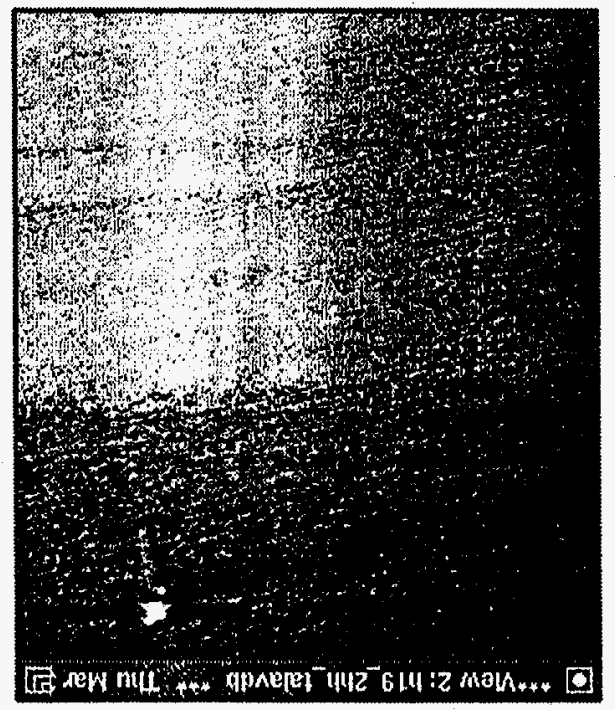

ayen 6uans e jo ajdurexg : 2 ann6|y

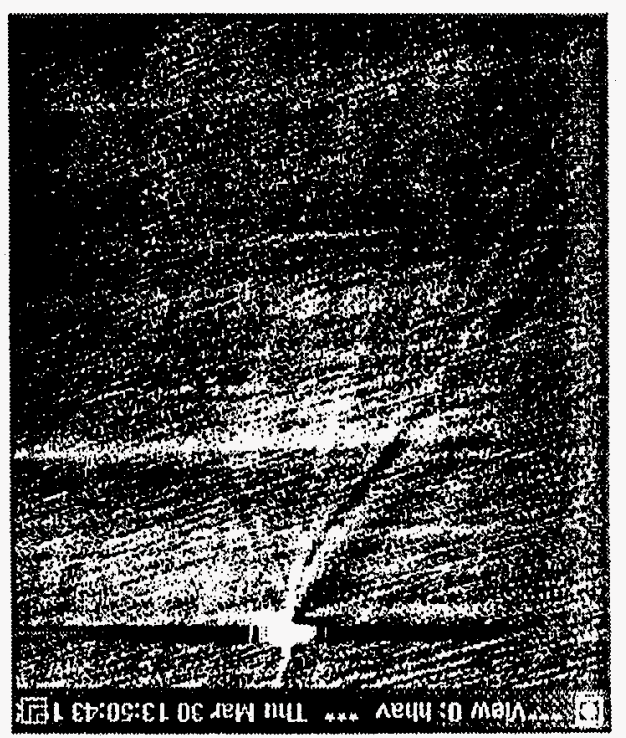




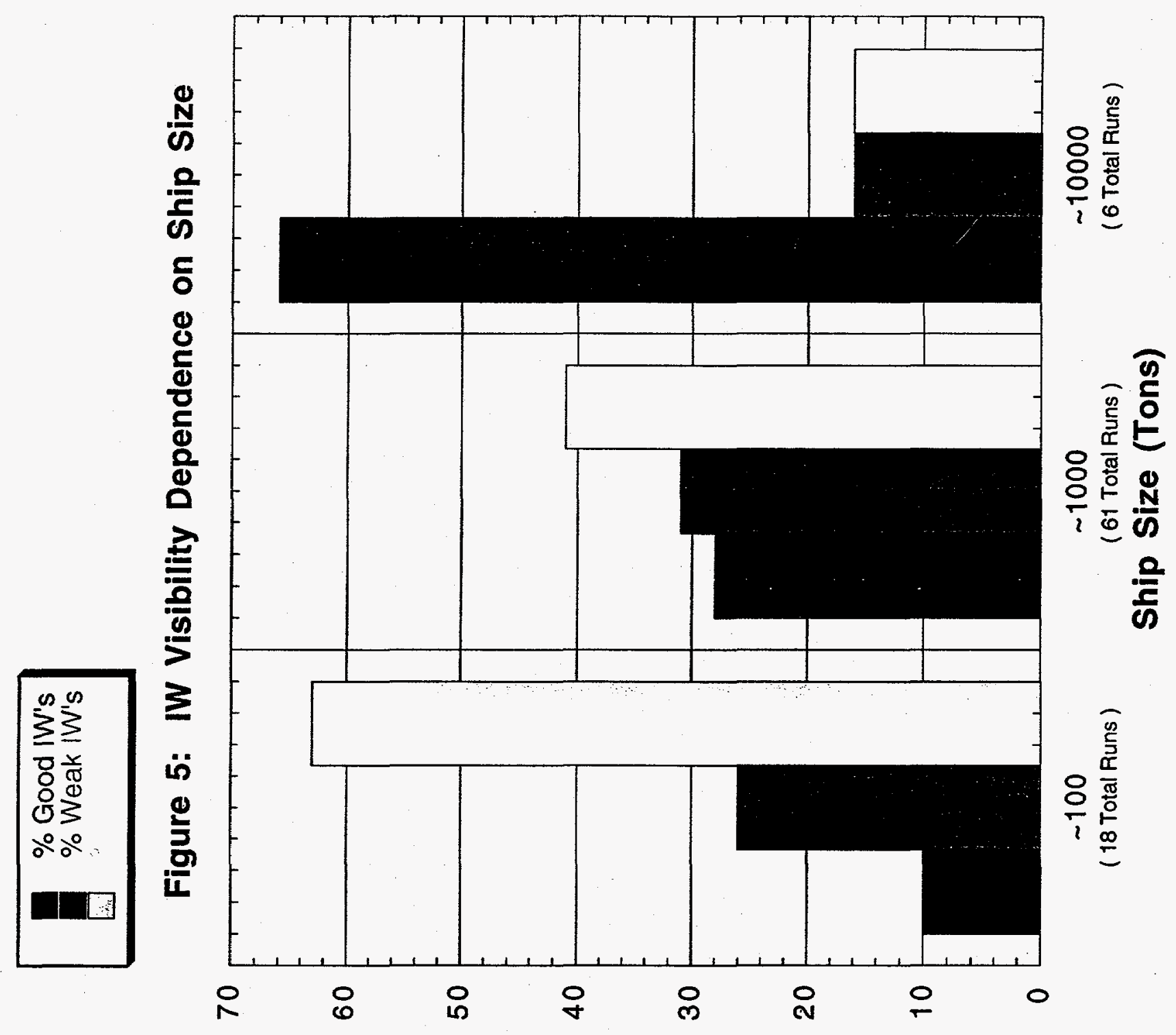

suny to obequorsod 


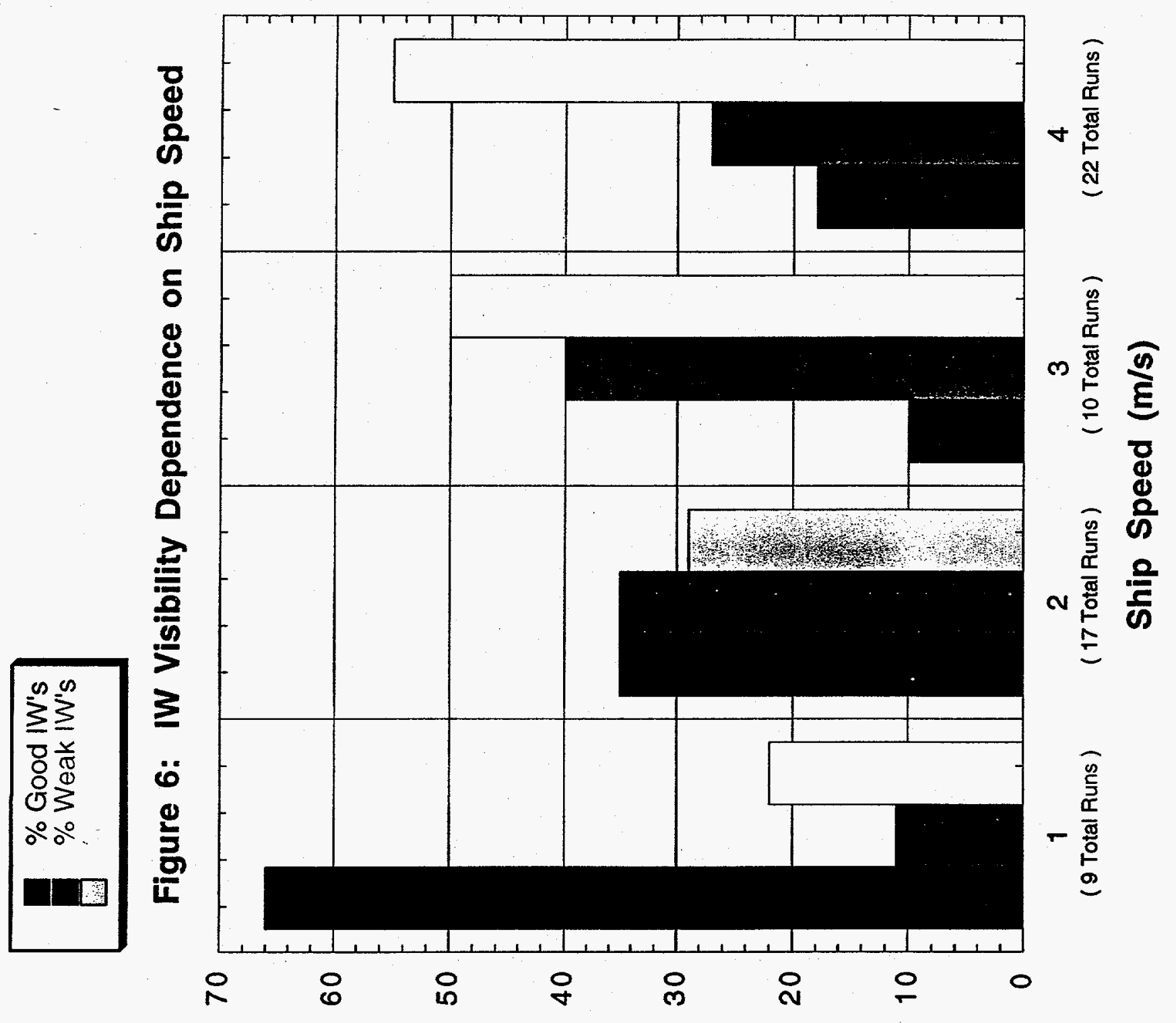

suny to ә6ejuasdad 


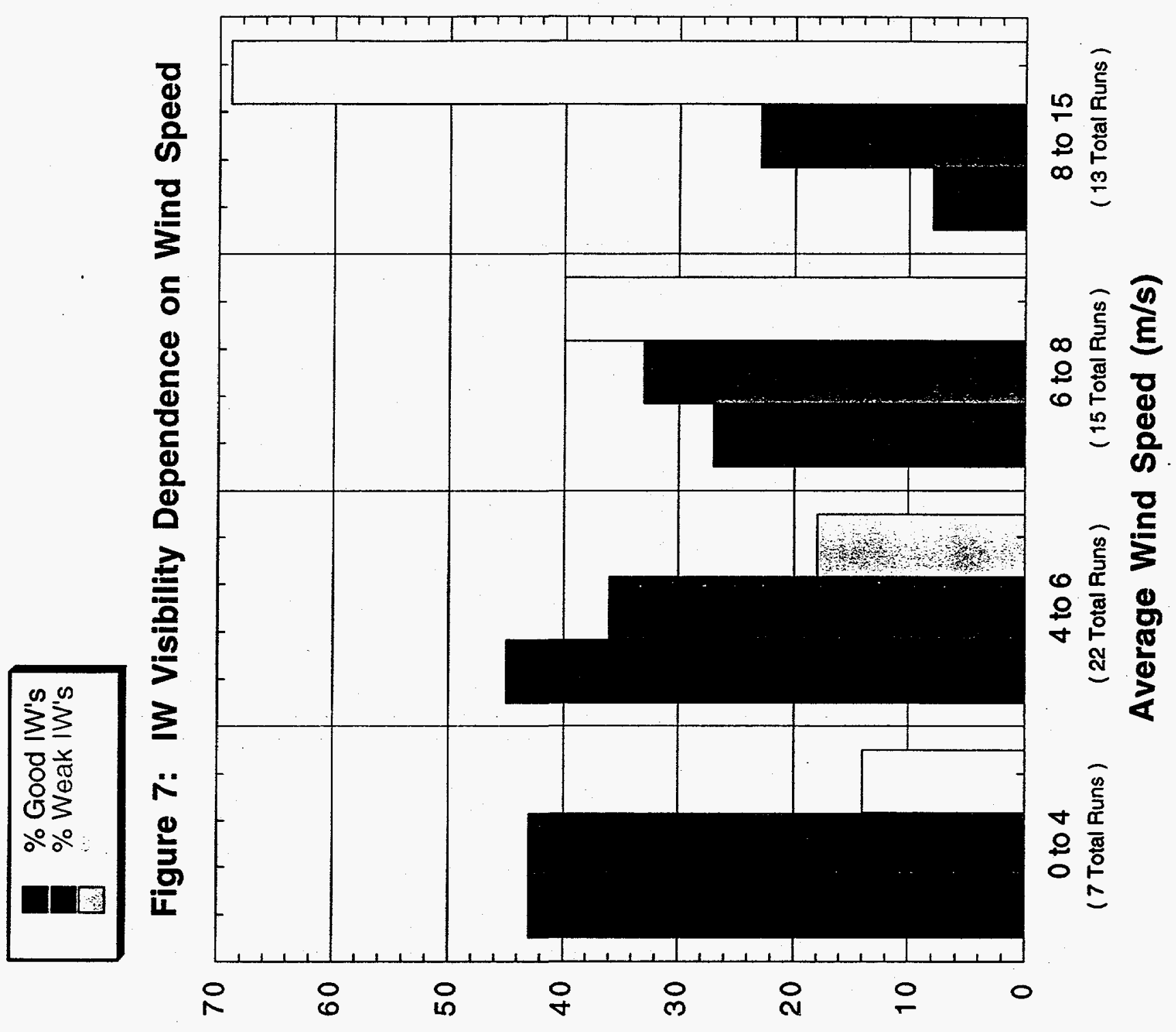

suny to eбejuəssad 


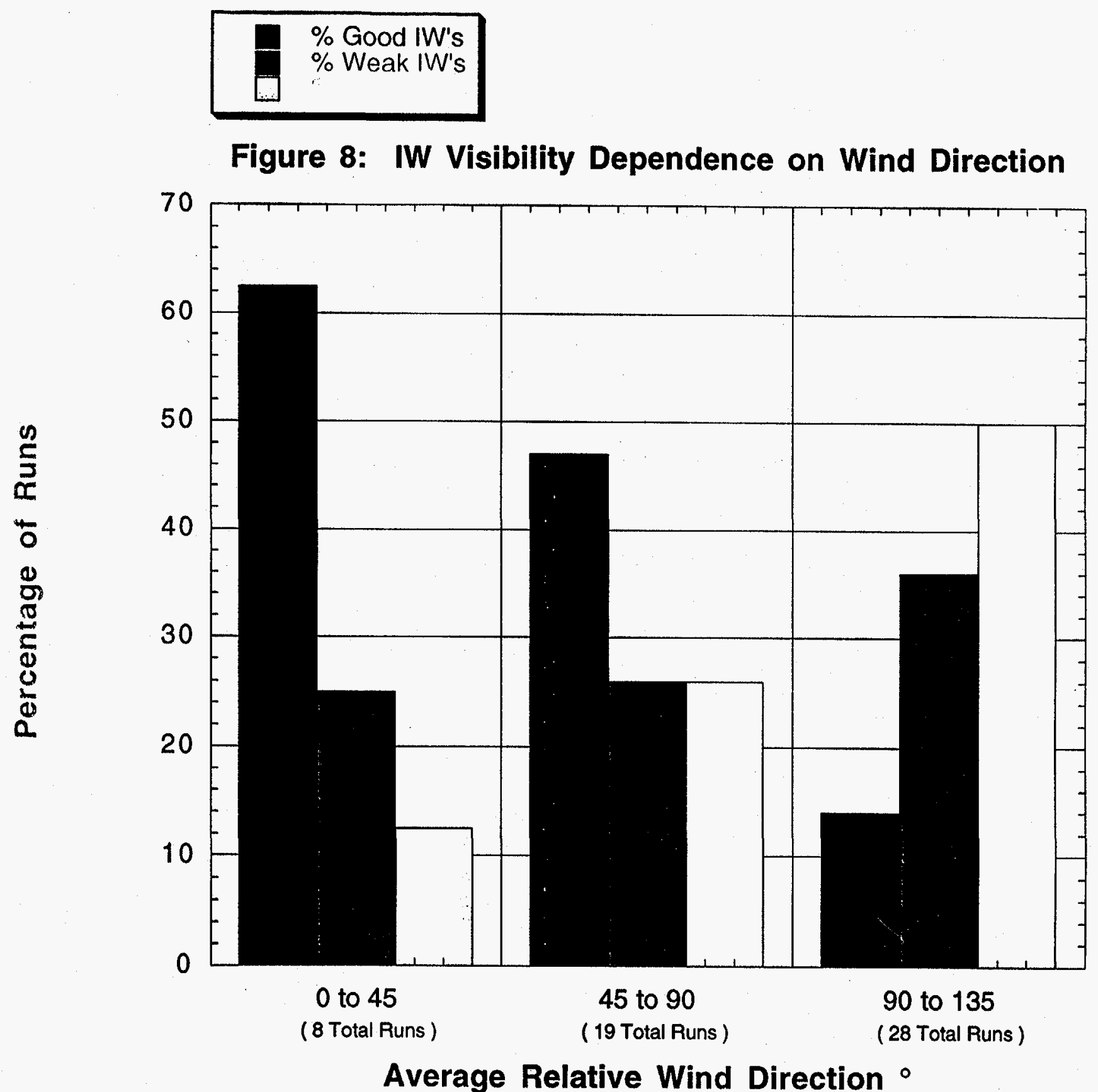




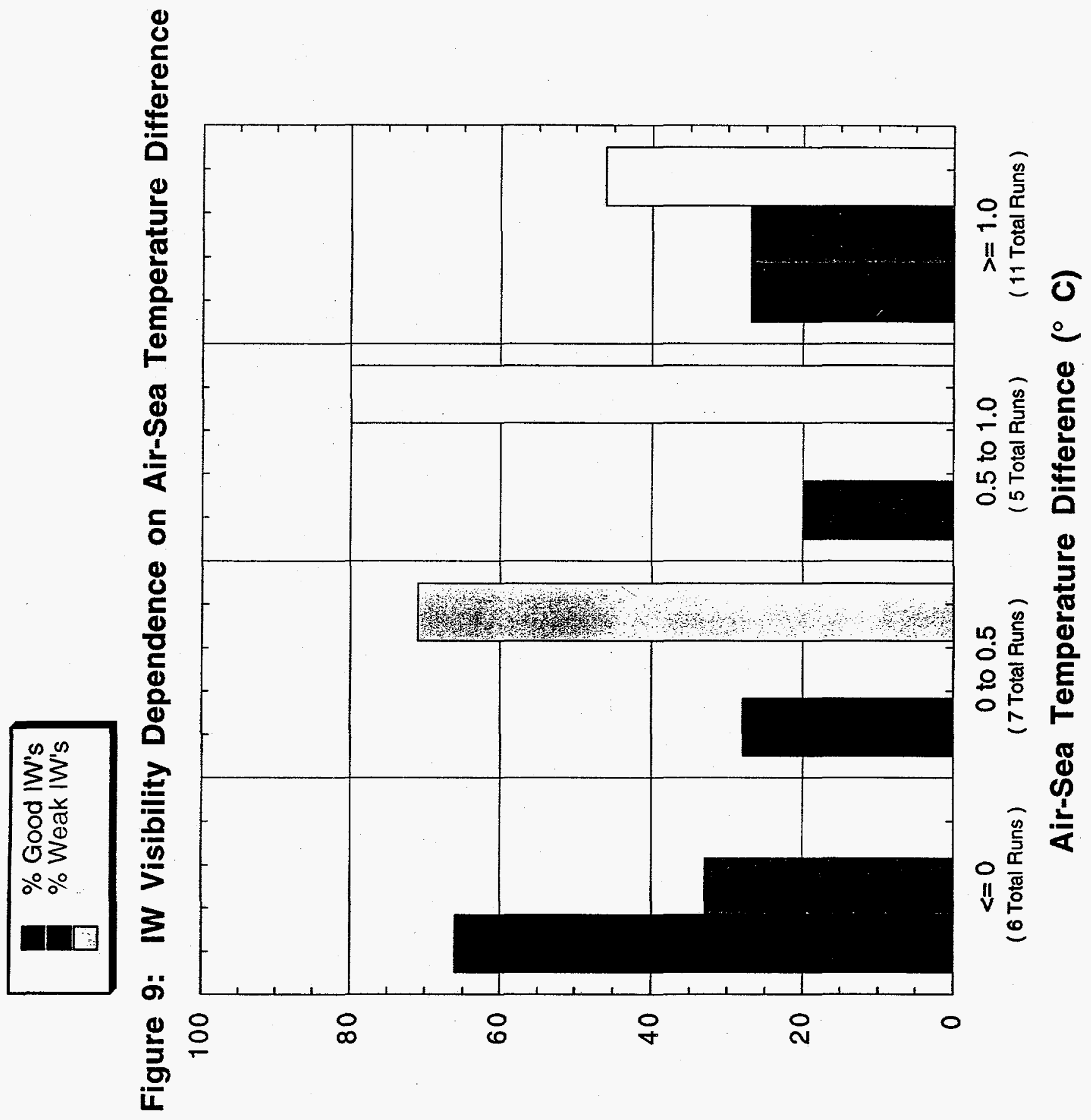

suny to eбefuəos.d 


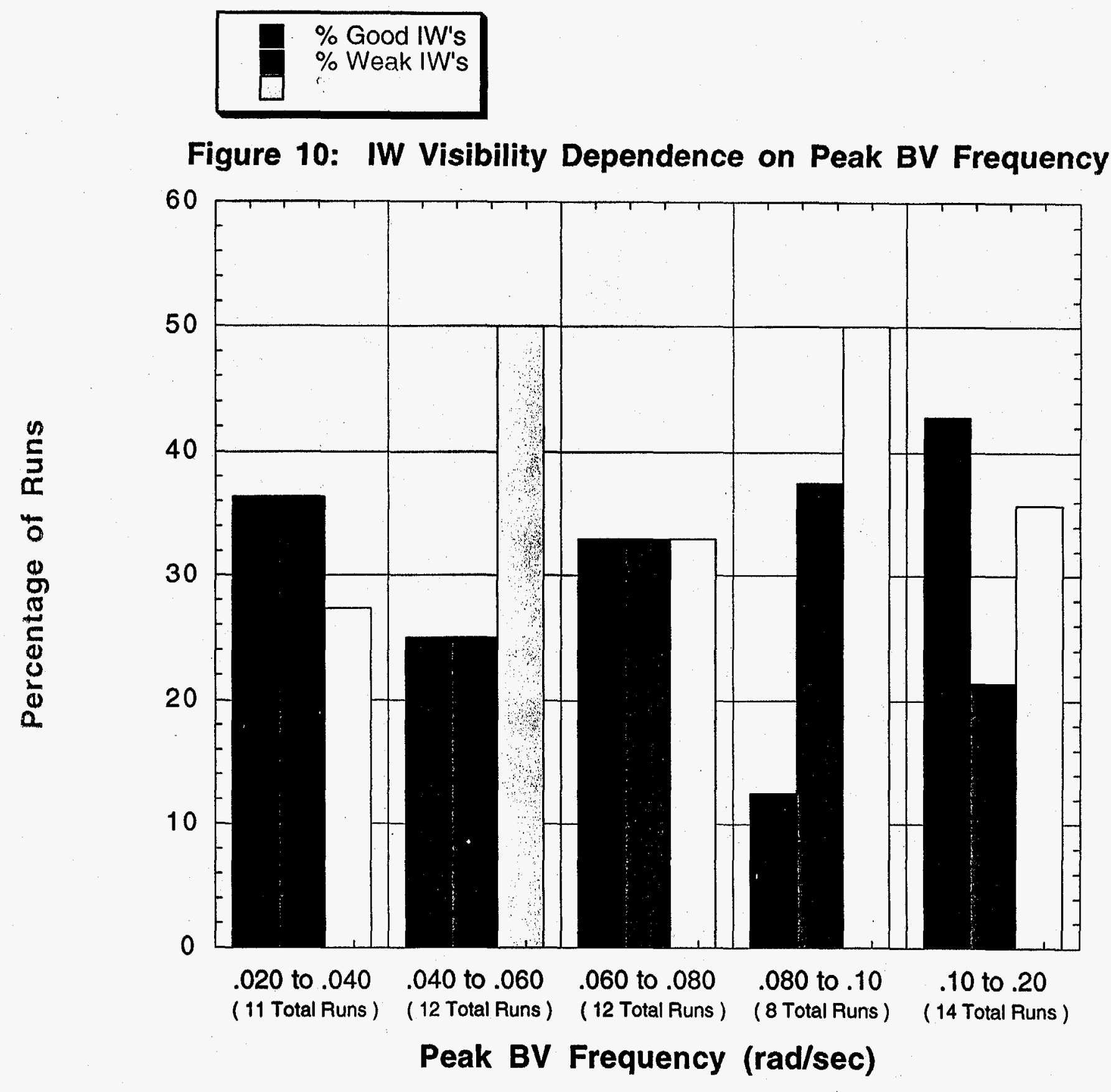




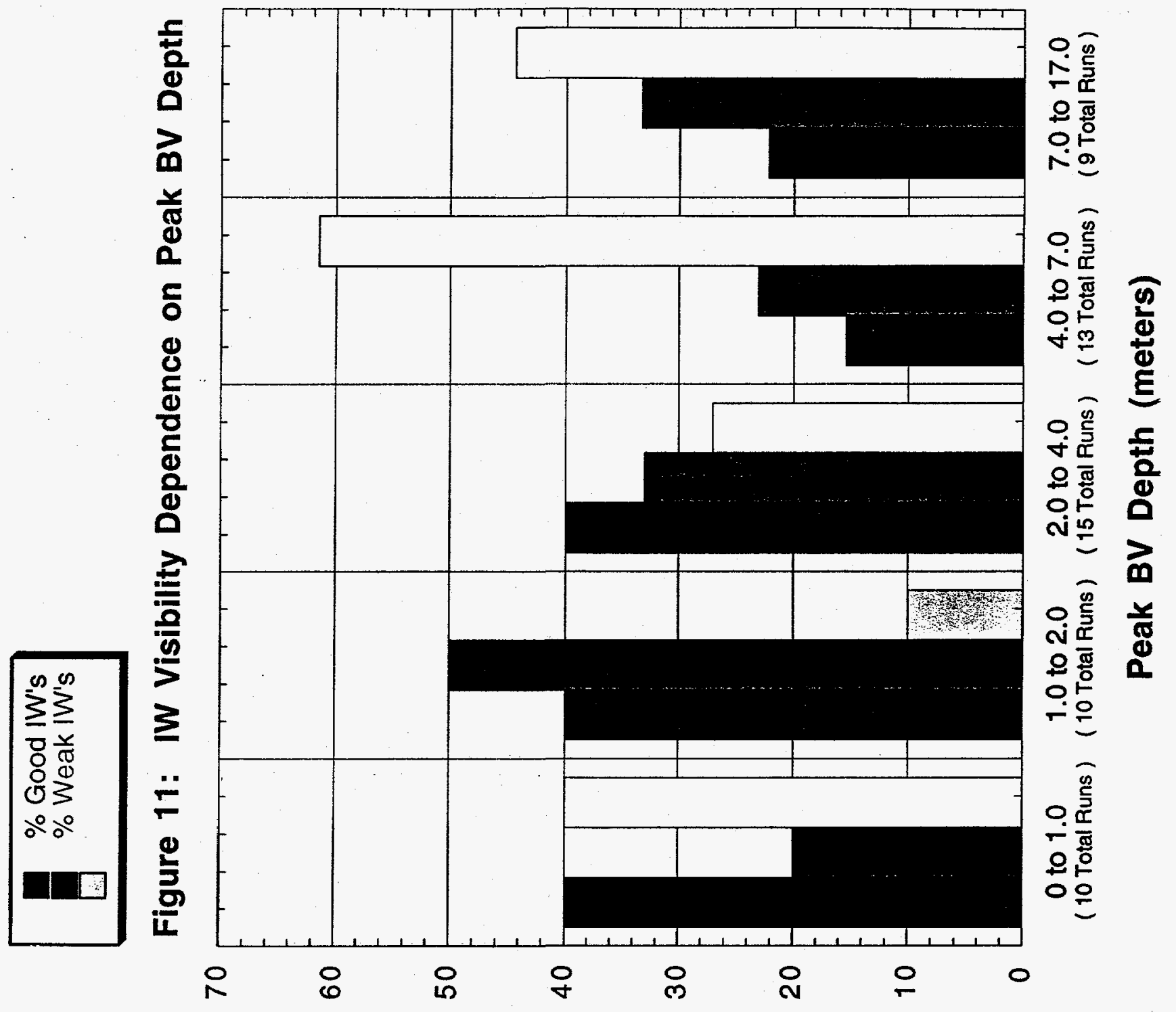

suny to ә6equәs, d 